\title{
Pten (phosphatase and tensin homologue gene) haploinsufficiency promotes insulin hypersensitivity
}

\author{
J. T. Wong $\cdot$ P. T. W. Kim $・$ J. W. Peacock $・$ T. Y. Yau $\cdot$ \\ A. L.-F. Mui • S. W. Chung • V. Sossi $\cdot$ D. Doudet • \\ D. Green • T. J. Ruth • R. Parsons • C. B. Verchere • \\ C. J. Ong
}

Received: 9 August 2006 / Accepted: 18 September 2006 / Published online: 29 December 2006

(C) Springer-Verlag 2006

\begin{abstract}
Aims/hypothesis Insulin controls glucose metabolism via multiple signalling pathways, including the phosphatidylinositol 3-kinase (PI3K) pathway in muscle and adipose tissue. The protein/lipid phosphatase Pten (phosphatase and tensin homologue deleted on chromosome 10) attenuates PI3K signalling by dephosphorylating the phosphatidyli-
\end{abstract}

J. T. Wong $\cdot$ J. W. Peacock $\cdot$ T. Y. Yau $\cdot$ C. J. Ong $(\bowtie)$

The Prostate Centre at Vancouver General Hospital,

Vancouver Coastal Health Research Institute,

2660 Oak Street,

Vancouver, BC, Canada V6H $3 Z 6$

e-mail: chriso@interchange.ubc.ca

J. T. Wong • P. T. W. Kim • J. W. Peacock $\cdot$ T. Y. Yau

A. L.-F. Mui $\cdot$ S. W. Chung $\cdot$ C. J. Ong

Department of Surgery, University of British Columbia,

Vancouver, BC, Canada

C. B. Verchere

Department of Pathology and Laboratory Medicine,

University of British Columbia,

Vancouver, BC, Canada

V. Sossi

Department of Physics, University of British Columbia,

Vancouver, BC, Canada

D. Doudet $\cdot$ T. J. Ruth

TRIUMF,

Vancouver, BC, Canada

D. Green

British Columbia Cancer Research Institute,

Vancouver, BC, Canada

R. Parsons

Institute of Cancer Genetics, College of Physicians and Surgeons,

Columbia University,

New York, NY, USA nositol 3,4,5-trisphosphate generated by PI3K. The current study was aimed at investigating the effect of haploinsufficiency for Pten on insulin-stimulated glucose uptake.

Materials and methods Insulin sensitivity in Pten heterozygous $\left(\mathrm{Pten}^{+-}\right)$mice was investigated in i.p. insulin challenge and glucose tolerance tests. Glucose uptake was monitored in vitro in primary cultures of myocytes from $\mathrm{Pten}^{+/-}$mice, and in vivo by positron emission tomography. The phosphorylation status of protein kinase B (PKB/Akt), a downstream signalling protein in the PI3K pathway, and glycogen synthase kinase $3 \beta$ (GSK3 $\beta$ ), a substrate of PKB/ Akt, was determined by western immunoblotting.

Results Following i.p. insulin challenge, blood glucose levels in Pten $^{+/-}$mice remained depressed for up to $120 \mathrm{~min}$, whereas glucose levels in wild-type mice began to recover after approximately $30 \mathrm{~min}$. After glucose challenge, blood glucose returned to normal about twice as rapidly in $\mathrm{Pten}^{+/-}$mice. Enhanced glucose uptake was observed both in $\mathrm{Pten}^{+/-}$myocytes and in skeletal muscle of Pten $^{+/-}$mice by PET. PKB and GSK3 $\beta$ phosphorylation was enhanced and prolonged in $\mathrm{Pten}^{+/-}$myocytes.

Conclusions/interpretation Pten is a key negative regulator of insulin-stimulated glucose uptake in vitro and in vivo. The partial reduction of Pten due to Pten haploinsufficiency is enough to elicit enhanced insulin sensitivity and glucose tolerance in $\mathrm{Pten}^{+/-}$mice.

Keywords Glucose uptake · Insulin hypersensitivity . Insulin sensitivity $\cdot$ Pten haploinsufficiency
Abbreviations
${ }^{18} \mathrm{FDG} \quad 2-\left[{ }^{18} \mathrm{~F}\right]$ fluoro-2-deoxyglucose
GSK3 glycogen synthase kinase 3
PET positron emission tomography
PI3K phosphatidylinositol 3-kinase 
$\mathrm{PIP}_{3} \quad$ phosphatidylinositol 3,4,5-trisphosphate

PKB protein kinase B

Pten phosphatase and tensin homologue

SHIP2 SH2-containing inositol 5'-phosphatase 2 (also known as INPP5D)

\section{Introduction}

Type 2 diabetes mellitus is a multifactorial disease with a complex pathophysiology that includes defects in insulin production and a failure in peripheral tissues to take up glucose in response to insulin. Signalling via phosphatidylinositol 3-kinase (PI3K) is a key pathway in the regulation of glucose uptake by insulin [1]. Activation of PI3K via insulin receptor substrate- 1 causes $\mathrm{PI} 3 \mathrm{~K}$ to phosphorylate inositol-containing phospholipids at the 3'-position of the inositol ring, increasing the levels of the lipid messenger phosphatidylinositol 3,4,5-trisphosphate $\left(\mathrm{PIP}_{3}\right)$, among others. $\mathrm{PIP}_{3}$ activate a phosphoinositide kinases, which in turn phosphorylate and activate protein kinase $\mathrm{B}$ (PKB), also known as Akt, a key effector kinase for many of the downstream metabolic effects initiated by insulin via PI3K. The phosphatase and tensin homologue (PTEN) is a phosphatase which recognises both protein and lipid substrates. As a lipid phosphatase, PTEN dephosphorylates $\mathrm{PIP}_{3}$ at the $3^{\prime}$-position of the inositol ring, thereby acting as an antagonist to PI3K signalling [2, 3]. PTEN was originally identified as a tumour suppressor gene, and is one of the most commonly mutated genes in human cancer [4-6]. Mutation or deletion of PTEN has been identified in many cancers including prostate, brain, breast, endometrium and skin [4-8].

As many of the metabolic outcomes of insulin are achieved through recruitment of PI3K and the subsequent rise in $\mathrm{PIP}_{3}$ levels, PTEN may have a critical role in modulating sensitivity to insulin-stimulated glucose uptake. Recent studies in which Pten was ablated specifically in liver, adipose tissue and muscle in mice by Cre recombinase-based strategies have shown a role for Pten in the regulation of insulin sensitivity in those organs, and highlighted the contributions of those organs to glucose homeostasis of the whole animal [9-11]. However, the effect of global reduction of Pten levels on glucose uptake and metabolism has not yet been shown in an in vivo mouse model. Unfortunately, experimental genetic inactivation of both Pten alleles $\left(\right.$ Pten $\left.^{-/}\right)$results in early embryonic lethality [6, 12]. Thus mice harbouring inactivation of one Pten allele (haploinsufficiency, Pten ${ }^{+-}$) are an important experimental model for studying the role of Pten in vivo. Haploinsufficiency for Pten has important consequences for cell proliferation and tumorigenesis in mice [6, 12-14]. Pten $^{+--}$mice exhibit defective apoptosis in $\mathrm{T}$ cells, B cells and macrophages and spontaneous neoplasms in various tissues including prostate, liver, endometrium and others [12-14]. Here we show that Pten haploinsufficiency results in insulin hypersensitivity and enhanced insulin-mediated glucose uptake.

\section{Materials and methods}

Experimental animals All laboratory animals were cared for and used according to guidelines of the Canadian Council on Animal Care. Pten ${ }^{+/-}$mice were generated by R. Parsons [12]. These mice were backcrossed with C57BL6 mice for more than ten generations. The genotypes of the mice were determined as described [12].

Blood glucose determination For determination of blood glucose levels, glucose levels in blood samples taken from tail vein were determined using a One Touch Ultra blood glucose monitor (LifeScan Inc., Milpitas, CA, USA). For the glucose tolerance test, mice were fasted overnight $(15 \mathrm{~h})$ prior to i.p. injection of glucose $(2 \mathrm{mg} / \mathrm{g}$ body weight). Blood glucose levels were then determined at the indicated time-points following glucose injection. For the insulin challenge test, mice were fasted for $15 \mathrm{~h}$ prior to i.p. injection of $0.6 \mathrm{mU}$ insulin/g body weight. Blood glucose levels were then determined at the indicated time-points following insulin injection.

Determination of insulin in plasma Mice were fasted for $15 \mathrm{~h}$, then approximately $100 \mu \mathrm{l}$ of blood was collected from the tail vein using pipette tips precoated with heparin. The mice were then injected i.p. with $2 \mathrm{mg}$ glucose/g body weight, and a second blood sample was obtained $15 \mathrm{~min}$ following injection. The blood samples were centrifuged at $805 \mathrm{~g}$ in a table-top centrifuge, and insulin in the plasma fraction was determined using an insulin ELISA system (ALPCO Diagnostics, Salem, NH, USA) according to the manufacturer's instructions.

Isolation of pancreatic islets and glucose-stimulated insulin release Islets were isolated from pancreata of mice as described [15]. Pancreata from three mice were pooled. After $24 \mathrm{~h}$ in culture, islets were preincubated in KrebsRinger bicarbonate buffer plus $0.1 \%$ BSA (KRBB-BSA) and $1.67 \mathrm{mmol} / 1$ glucose. The islet cells were incubated for $1 \mathrm{~h}$ in $1 \mathrm{ml}$ KRBB-BSA containing the desired concentration of glucose $(1.67$ or $16.7 \mathrm{mmol} / \mathrm{l})$. The incubation medium was then collected, and centrifuged and the supernatant fractions were used for assay of insulin content by ELISA. Total extractable insulin in islets was determined by adding $0.5 \mathrm{ml}$ lysis buffer $(1 \mathrm{~mol} / 1$ acetic acid 
with $0.1 \% \mathrm{BSA}$ ) to the islet pellet. Cell debris was pelleted by centrifugation, and the supernatant fraction was used for insulin assay.

Fluorescent immunohistochemistry of pancreatic islets Immunocytochemistry has been described [16]. Pancreata from wild-type and Pten $^{+-}$mice were embedded in paraffin. Five-micron sections were incubated for $1 \mathrm{~h}$ at room temperature with guinea-pig anti-insulin antibody (1:100 dilution; Dako, Mississagua, ON, Canada) and rabbit anti-glucagon antibody (Dako; 1:75 dilution). Sections were visualised by incubation with Alexa-Fluor 488 goat anti-guinea-pig (Invitrogen, Molecular Probes, Burlington, ON, Canada; 1:100 dilution) and Texas Red donkey anti-rabbit antibodies (Jackson ImmunoResearch Laboratories, West Grove, PA, USA; 1:100 dilution). Sections were examined by fluorescence microscopy.

Beta cell mass calculation Following insulin immunostaining, pancreatic sections were captured under an FITC filter using a Zeiss Axioplan 2 microscope equipped for epifluorescence and Pathvysion imaging software. The insulin immunopositive area (as a proportion of pancreatic area) was determined in at least six fields per section using Zeiss AxioVision software, performed on eight pancreatic sections per mouse. Beta cell mass was calculated as pancreatic mass times the percent beta cell area for each mouse.

$2-\left[{ }^{18}\right.$ F]fluoro-2-deoxyglucose uptake and microPET scanning Mice were fasted for $15 \mathrm{~h}$ prior to i.p. injection with $0.6 \mathrm{mU}$ insulin/g body weight. Twenty minutes after insulin injection, mice were injected with 2-[ $\left[{ }^{18} \mathrm{~F}\right]$ fluoro-2deoxyglucose $\left({ }^{18} \mathrm{FDG}\right)(4.1 \mathrm{MBq})$ via the tail vein, and whole-body distribution of ${ }^{18}$ FDG was monitored by positron emission tomography (PET) using a microPET R4 tomograph (Concorde Microsystems, Knoxville, TN, USA). The image data were attenuation-corrected using a ${ }^{68} \mathrm{Ge}$ rod source. Wild-type and $\mathrm{Pten}^{+/-}$mice were positioned side-by-side and scanned simultaneously for 60 min after ${ }^{18}$ FDG injection. Data were analysed using the manufacturer's software, ASIPro VM 5.0.1.0. For data analysis, regions of interest (ROIs) were specified in the coronal section of a hindlimb for each mouse. The ${ }^{18} \mathrm{FDG}$ activities in each ROI were summed across all coronal planes, and expressed as a proportion of ${ }^{18} \mathrm{FDG}$ in the whole mouse (total ${ }^{18}$ FDG activity was also taken as the sum of activity across coronal planes).

Primary myocyte culture Primary myocytes were cultured from fore- and hindlimbs from wild-type and $\mathrm{Pten}^{+/-}$mice according to a protocol adapted from Springer et al. [17]. Skeletal muscle was excised and minced and then incubated at $37^{\circ} \mathrm{C}$ for $2 \mathrm{~h}$ with 2.4 units $/ \mathrm{ml}$ dispase II. Dispase digestion was halted by addition of $10 \mathrm{ml} \mathrm{F-10-based}$ myocyte medium (400 ml F-10 nutrient mixture, $100 \mathrm{ml}$ fetal bovine serum, $25 \mu \mathrm{g}$ basic fibroblast growth factor, penicillin/streptomycin). The tissue slurry was then strained through a fine metal mesh and centrifuged at $500 \mathrm{~g}$ for 5 min. The supernatant fraction was removed to a fresh centrifuge tube and the pellet was resuspended and plated to a 5-cm collagen-coated culture dish in a total of $4 \mathrm{ml}$ F-10-based medium. The supernatant fraction was recentrifuged and the pellet was pooled with the first. The cells were passaged when they reached $70-80 \%$ confluence. To enrich for myocytes, the old medium was removed by aspiration, the cells washed with PBS, then incubated in a film of this buffer for $15 \mathrm{~min}$. Myocytes were loosened from the dish by striking the dish several times sharply on the bench top. Cells were washed from the dish with PBS. The PBS incubation was repeated and the cells were pooled. Cells kept in culture for more than 5-6 days began to exhibit the elongated morphology typical of myotubes [18]. Cells in these older cultures also exhibited spontaneous twitching. All experiments were performed with cells on days 2-3 of culture.

2-Deoxy $[3 \mathrm{H}]$ glucose uptake Experiments were performed on wild-type or Pten $^{+/-}$cells from passage two to eight, grown on 24-well (1-cm diameter wells) plates. Cells were preincubated in serum-free medium for $12 \mathrm{~h}$ prior to experiments. The cells were washed twice with HEPESbuffered saline (140 mmol/l NaCl, $20 \mathrm{mmol} / \mathrm{l}$ HEPES, $2.5 \mathrm{mmol} / 1 \mathrm{MgSO}_{4}, 1 \mathrm{mmol} / \mathrm{CaCl}_{2}, 5 \mathrm{mmol} / 1 \mathrm{KCl}, \mathrm{pH}$ 7.4), then incubated with $10 \mu \mathrm{mol} / 12$-deoxy $\left[{ }^{3} \mathrm{H}\right]$ glucose $(0.037 \mathrm{MBq} / \mathrm{ml})$ for $5,10,20$ or $30 \mathrm{~min}$, in the absence or presence of $0.1 \mu \mathrm{mol} / 1$ insulin. At the end of the incubation period, the radioactive substrate was removed, and the cells were washed three times with ice-cold $20 \mathrm{mmol} / 1$ glucose. Cells were lysed with $0.2 \mathrm{ml} \mathrm{2 \%} \mathrm{SDS}$, and the lysates were used for scintillation counting. Non-specific diffusion of 2deoxy $\left[{ }^{3} \mathrm{H}\right]$ glucose was determined by incubating cells in the presence of 2-deoxy $\left[{ }^{3} \mathrm{H}\right]$ glucose and $10 \mu \mathrm{mol} / \mathrm{l}$ cytochalasin B, a specific inhibitor of glucose uptake [19].

Determination of cell-surface GLUT1 and GLUT4 levels Primary myocytes were grown in 10-cm culture dishes. The cells were rinsed with PBS, and incubated with $0.5 \mathrm{mg} / \mathrm{ml}$ sulpho-NHS-LC-biotin (Pierce Biotechnology, Rockford, IL, USA) in PBS for $20 \mathrm{~min}$. Cells are impermeable to this reagent and it labels the amine groups of cell-surface proteins. Following the incubation, the cells were washed three times with $\mathrm{PBS}$, then lysed with $0.5 \mathrm{ml}$ lysis buffer

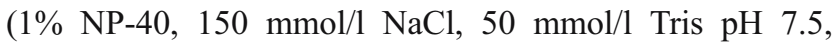
including protease and phosphatase inhibitors). Protein was quantified with a BCA protein assay kit (Pierce). Strepta- 
Table 1 Blood glucose levels in wild-type and $\mathrm{Pten}^{+/-}$mice during ad libitum feeding and after a 15 -h fast

\begin{tabular}{llll}
\hline & \multicolumn{2}{l}{$\begin{array}{l}\text { Mean blood glucose } \pm \text { SD } \\
(\mathrm{mmol} / \mathrm{l})\end{array}$} & $\begin{array}{l}p \text { value (independent } \\
\text { Student's } t \text { test })\end{array}$ \\
\cline { 2 - 3 } & Wild-type & Pten $^{+-}$ & \\
\hline $\begin{array}{c}\text { Ad libitum } \\
\text { feeding }\end{array}$ & $\begin{array}{c}7.1 \pm 0.4 \\
(n=5)\end{array}$ & $\begin{array}{c}6.3 \pm 0.2 \\
(n=4)\end{array}$ & 0.006 \\
Fasting & $\begin{array}{c}6.5 \pm 0.3 \\
(n=5)\end{array}$ & $\begin{array}{c}5.8 \pm 0.3 \\
(n=5)\end{array}$ & 0.008 \\
\hline
\end{tabular}

vidin-agarose beads (Pierce) were pre-blocked by incubation with $2 \%$ BSA in lysis buffer. Each sample $(1.2 \mathrm{mg}$ protein) was incubated with the streptavidin beads $(100 \mu \mathrm{l}$, $50 \%$ bead slurry) for $1 \mathrm{~h}$ at room temperature. The beads were washed five times, for 30-60 min each wash, using lysis buffer containing $0.1 \%$ SDS. After the final wash, $50 \mu \mathrm{l}$ SDS sample-loading buffer were added, and heated at $95^{\circ} \mathrm{C}$ for $10 \mathrm{~min}$, then vortexed to elute the biotinylated proteins. The proteins in the supernatant fractions were analysed by SDS-PAGE, then transferred to nitrocellulose. Proteins were probed using polyclonal antibodies against GLUT1 and GLUT4 (also known as SCLA2A1 and SCLA2A4, respectively).

Western immunoblotting for $P K B$, phospho- $P K B$ and phospho-glycogen synthase kinase 3 (GSK3)- $\alpha / \beta$ Total protein extracts of primary myocytes were prepared by lysing cells in NP-40-based lysis buffer. Thirty to fifty micrograms of protein per sample were analysed by SDSPAGE, then transferred to nitrocellulose. Rabbit polyclonal anti-PKB, anti-phospho-PKB (Ser473) and anti-phosphoGSK3- $\alpha / \beta$ (Ser21/9) antibodies were obtained from Cell Signaling Technology (Beverly, MA, USA). Mouse monoclonal anti-vinculin antibody was obtained from Sigma ( $\mathrm{St}$ Louis, MO, USA). Horseradish peroxidase-conjugated secondary antibodies were obtained from Dako. Protein bands were visualised using an enhanced chemiluminescence system and autoradiography by exposure to X-ray film.

Statistical analysis Statistical analysis was performed using Student's $t$ test. Significance was assessed at the 95\% confidence level.

\section{Results}

As glucose metabolism may be altered due to a change in insulin sensitivity in $\mathrm{Pten}^{+/-}$mice, blood glucose levels in wild-type and Pten $^{+/-}$mice were determined. Slight but statistically significant hypoglycaemia was observed in $\mathrm{Pten}^{+-}$mice during ad libitum feeding $(11.3 \%$ lower blood glucose in $\mathrm{Pten}^{+/-}$mice) (Table 1). Fasting caused a drop in glucose levels in both groups, with slight but significant hypoglycaemia in the Pten $^{+-}$group $(10.8 \%$ lower blood glucose) relative to wild-type mice. An insulin challenge test revealed hypersensitivity to insulin in $\mathrm{Pten}^{+/-}$mice (Fig. 1a). Following i.p. insulin injection $(0.6 \mathrm{mU} / \mathrm{g}$ body weight), blood glucose levels in Pten ${ }^{+/-}$mice remained depressed at all time-points measured (up to $120 \mathrm{~min}$ ). In contrast, wild-type mice started to recover after $30 \mathrm{~min}$, and glucose levels returned to fasting levels $120 \mathrm{~min}$ after injection. A glucose tolerance test showed that $\mathrm{Pten}^{+/-}$mice had greater glucose tolerance than wild-type mice (Fig. 1b). After i.p. glucose injection, blood glucose levels in $\mathrm{Pten}^{+-}$ mice returned to fasting levels in less than $60 \mathrm{~min}$, approximately twice as rapidly as in wild-type mice.
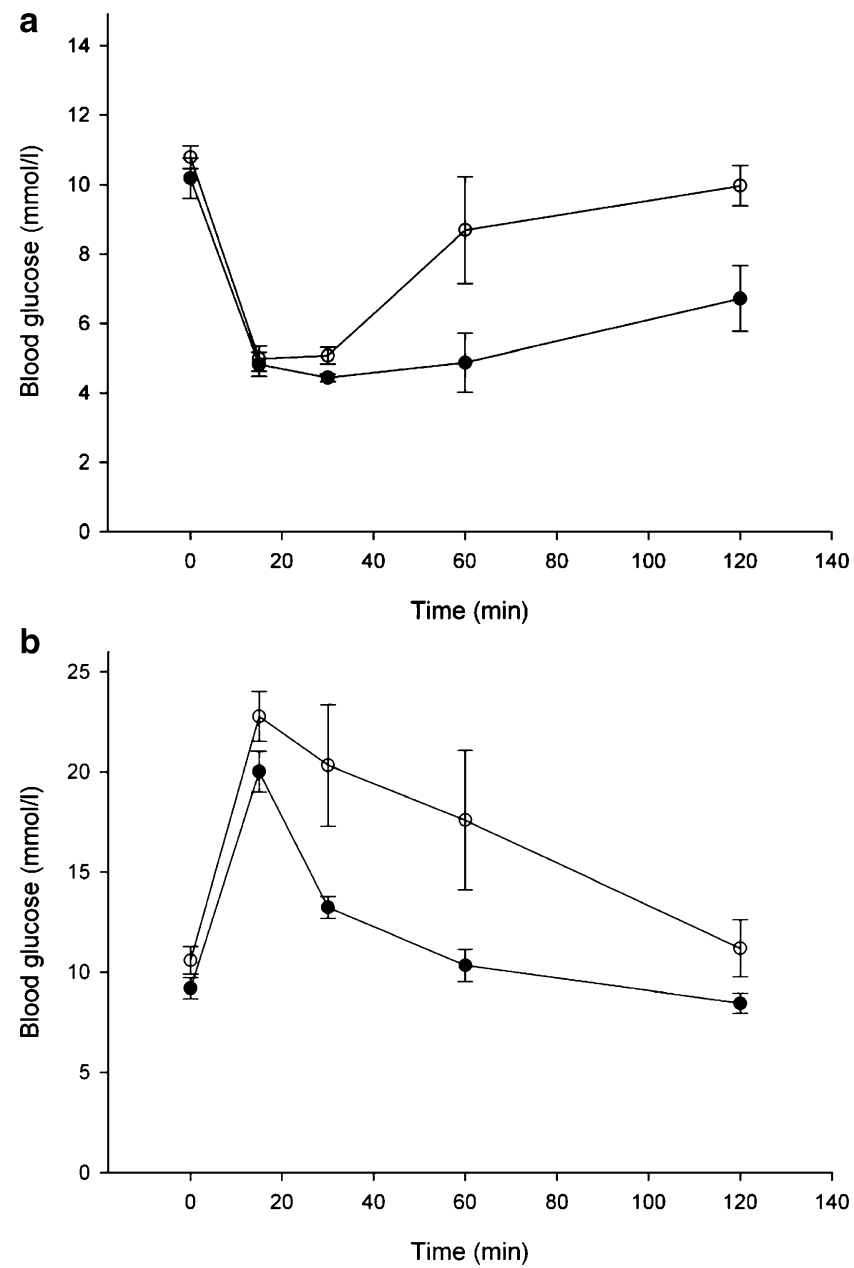

Fig. 1 Insulin hypersensitivity in $\mathrm{Pten}^{+-}$mice. a Insulin challenge test. Mice were fasted for $15 \mathrm{~h}$ prior to i.p. injection of insulin ( $0.6 \mathrm{mU} / \mathrm{g}$ body weight). Blood glucose levels were determined at the indicated times. Means \pm SEM for six wild-type mice (white circles) and six $\mathrm{Pten}^{+/-}$mice (black circles). b Glucose tolerance test. Mice were fasted for $15 \mathrm{~h}$ prior to i.p. injection of glucose at $2 \mathrm{mg} / \mathrm{g}$ body weight. Means \pm SEM for six wild-type mice (white circles) and seven Pten $^{+/-}$mice (black circles) 
Table 2 Plasma insulin levels in wild-type and $\mathrm{Pten}^{+/-}$mice after fasting, and $15 \mathrm{~min}$ after i.p. glucose administration ( $2 \mathrm{mg}$ glucose/g body weight)

\begin{tabular}{llll}
\hline & \multicolumn{2}{l}{$\begin{array}{l}\text { Mean plasma insulin } \pm \text { SD } \\
(\mathrm{ng} / \mathrm{ml})\end{array}$} & $\begin{array}{l}p \text { value (independent } \\
\text { Student's } t \text { test) }\end{array}$ \\
\cline { 2 - 3 } & $\begin{array}{l}\text { Wild-type } \\
(n=7)\end{array}$ & $\begin{array}{l}\mathrm{Pten}^{+/-} \\
(n=6)\end{array}$ & \\
\hline $\begin{array}{l}\text { Fasting } \\
\begin{array}{l}\text { Post-glucose } \\
\text { challenge }\end{array}\end{array}$ & $\begin{array}{l}0.50 \pm 0.04 \\
1.8 \pm 0.5\end{array}$ & $\begin{array}{l}0.36 \pm 0.10 \\
2.4 \pm 0.4\end{array}$ & $\begin{array}{l}0.05 \\
\text { che }\end{array}$ \\
\hline
\end{tabular}

The observed difference in ability to normalise blood glucose levels could be due to differences in insulin sensitivity or islet function and insulin production. We therefore investigated insulin levels in the mice, as well as properties of pancreatic cell morphology and function. Fasting plasma insulin levels were slightly but significantly lower in $\mathrm{Pten}^{+/-}$mice (Table 2), which is consistent with increased peripheral insulin sensitivity. Fifteen minutes after i.p. glucose administration ( $2 \mathrm{mg}$ glucose/g body weight), similar increases in plasma insulin were observed in the two groups (Table 2), suggesting that there is no marked difference in insulin production in the $\mathrm{Pten}^{+/-}$mice. Insulin released from islets isolated from $\mathrm{Pten}^{+/+}$and $\mathrm{Pten}^{+/}$ mice was also examined. Islets were cultured as described in Materials and methods, and incubated in the presence of low $(1.67 \mathrm{mmol} / \mathrm{l})$ or high $(16.7 \mathrm{mmol} / \mathrm{l})$ glucose. Insulin released into the medium was determined by ELISA and calculated as percentage of total insulin content in the islets. Per cent of total insulin release (presented as mean value \pm SD) was similar under conditions of low glucose $\left(\mathrm{Pten}^{+/+}\right.$, $3.3 \pm 0.4 \%$ vs Pten $^{+/-}, 2.8 \pm 0.3 \% ; p>0.05$ no significant difference, $n=3$ per group) and high glucose $\left(\mathrm{Pten}^{+/+}, 4.2 \pm\right.$ $0.7 \%$ vs Pten $^{+/-}, 3.7 \pm 0.2 \% ; p>0.05$ no significant difference, $n=3$ per group).

Immunofluorescence of pancreatic sections revealed similar morphology of islets of wild-type and $\mathrm{Pten}^{+/-}$mice (Fig. 2), suggesting Pten haploinsufficiency has no marked effect on islet morphology. Accordingly, beta cell mass was not found to be significantly different between wild-type and $\mathrm{Pten}^{+/-}$mice (Table 3).

Skeletal muscle is an important tissue involved in insulin-stimulated glucose uptake $[10,20]$. In vivo glucose uptake was assessed by monitoring distribution of ${ }^{18} \mathrm{FDG}$ into muscles in real-time by PET. ${ }^{18} \mathrm{FDG}$ is transported into cells by glucose transporters and is phosphorylated by hexokinase, but is not a substrate for further metabolism in the glycolytic pathway [21]. To compare insulin-stimulated glucose uptake in wild-type and ten $^{+/-}$mice, the mice were fasted for $15 \mathrm{~h}$, then injected i.p. with insulin $(0.6 \mathrm{mU} / \mathrm{g}$ body weight) $20 \mathrm{~min}$ prior to injection with ${ }^{18} \mathrm{FDG}$ via the tail vein. Mice were imaged for ${ }^{18} \mathrm{FDG}$ uptake into the hindlimb for $60 \mathrm{~min}$ (Fig. 3a). ${ }^{18} \mathrm{FDG}$ activity in hindlimbs was analysed as a proportion of total body activity, and was found to be higher in $\mathrm{Pten}^{+-}$than in wild-type mice at all time-points (Fig. 3b).

Tissues from $\mathrm{Pten}^{+-}$mice exhibited slightly reduced levels of Pten protein relative to wild-type mice [14, 2224]. In order to examine cellular glucose uptake and intracellular signalling events, primary myocytes were cultured from hindlimb muscle of wild-type and $\mathrm{Pten}^{+-}$ mice. In the absence of insulin, cells from $\mathrm{Pten}^{+/-}$mice showed increased 2-deoxy $\left[{ }^{3} \mathrm{H}\right]$ glucose uptake at all timepoints measured, to a maximum increase of twofold relative to wild-type cells at the $3 \mathrm{~h}$ time-point (Fig. 4a). This result, together with the lower fasting glucose level of $\mathrm{Pten}^{+/-}$mice, suggest that the PI3K/PKB pathway was chronically activated in Pten $^{+/-}$animals. In the presence of insulin, $\mathrm{Pten}^{+-}$cells exhibited a further increase in glucose uptake, up to threefold greater than wild-type cells. This observation is consistent with the above results of the insulin and glucose challenge tests and ${ }^{18} \mathrm{FDG}$ uptake experiment in showing a hypersensitivity to insulin due to Pten haploinsufficiency.

Glucose transport into skeletal muscle occurs by a facilitated diffusion process mediated primarily by the glucose transporter proteins, GLUT1 and GLUT4. The
Fig. 2 Pancreatic islet morphology and immunohistochemistry for insulin (green) and glucagon (red) in wild-type (a) and Pten $^{+/-}$(b) mice. Pancreatic sections were immunostained as described in Materials and methods and visualised by fluorescence microscopy. Original magnification $\times 40$ a

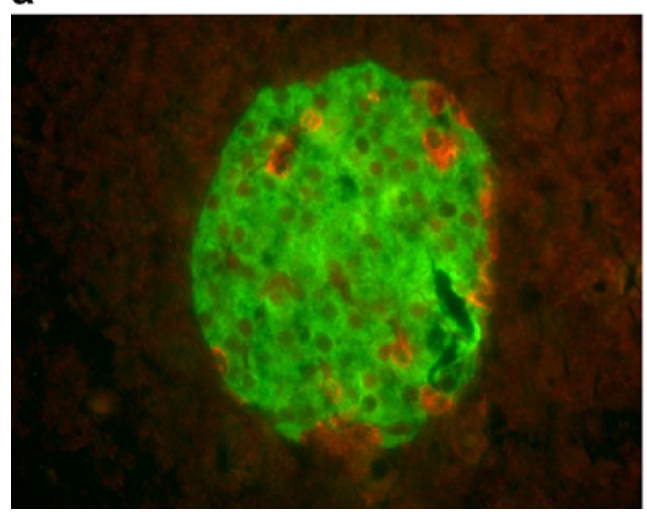

b

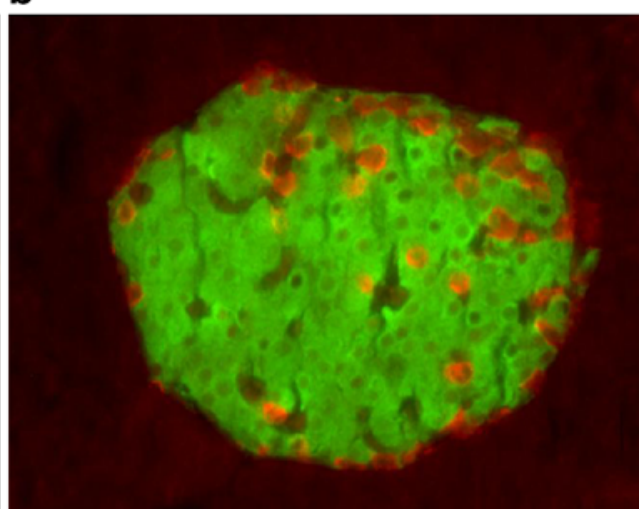


Table 3 Pancreatic beta cell mass of $\mathrm{Pten}^{+/+}$and Pten ${ }^{+/-}$littermates

Mean beta cell mass \pm SE (mg)

$\begin{array}{ll}\text { Pten }^{+/+} & 1.24 \pm 0.30(n=3) \\ \text { Pten }^{+/-} & 1.29 \pm 0.15(n=3)\end{array}$

level of GLUT4 at the plasma membrane is tightly regulated by insulin, whereas GLUT1 is found constitutively on the cell surface [25]. Since 2-deoxy[ $\left.{ }^{3} \mathrm{H}\right]$ glucose uptake was elevated in $\mathrm{Pten}^{+-}$cells even in the absence of insulin (Fig. 4a), we analysed cell-surface GLUT4 and GLUT1 by western immunoblot as described in Materials and methods (Fig. 4b). This analysis showed increased GLUT4 at the cell surface in Pten $^{+/-}$cells, while similar GLUT1 levels were observed in the two cell types.

As PKB is a key effector kinase that mediates many of the downstream cellular events induced by the PI3K signalling pathway, including insulin-stimulated glucose uptake $[26,27]$, we determined the phosphorylation status of PKB in wild-type and Pten ${ }^{+/-}$myocytes. Little to no phosphorylation was observed in the absence of insulin, and phosphorylation at Ser473 was observed upon addition of insulin (Fig. 5). Whereas PKB phosphorylation started to decrease after $4 \mathrm{~h}$ in wild-type cells in the presence of insulin, phosphorylation was sustained in $\mathrm{Pten}^{+/-}$cells during the course of the experiment (up to $6 \mathrm{~h}$ ). Immunoblotting for total PKB protein showed that PKB levels were consistent in $\mathrm{Pten}^{+/-}$and $\mathrm{Pten}^{+/+}$cells (Fig. 5). Immunoblotting for vinculin was included as a protein-loading control. An immediate downstream substrate of PKB is GSK $3 \beta$. This enzyme becomes inactivated upon phosphorylation by $\mathrm{PKB}$, in turn allowing its substrate, glycogen synthase, to mediate glycogen synthesis and thus promote glucose storage. Consistent with the observed enhancement of PKB phosphorylation in $\mathrm{Pten}^{+/-}$cells, these cells also exhibited a higher degree of GSK3 $\beta$ phosphorylation in comparison with $\mathrm{Pten}^{+/+}$cells (Fig. 5).

\section{Discussion}

Recent studies utilising tissue-specific deletion of Pten in liver, adipose and muscle have shown that these organs make important contributions to the glucose homeostasis of the animal and clearly establish Pten as a negative regulator of insulin signalling in vivo [9-11]. In a separate report, in vivo antisense treatment resulted in $90 \%$ reduction of Pten levels in the liver of diabetic mice, normalising blood glucose levels and improving performance in an insulin tolerance test [28]. While the above studies focused on the role of Pten in specific tissues, the current work defines the effects of partial systemic



\section{b}



c

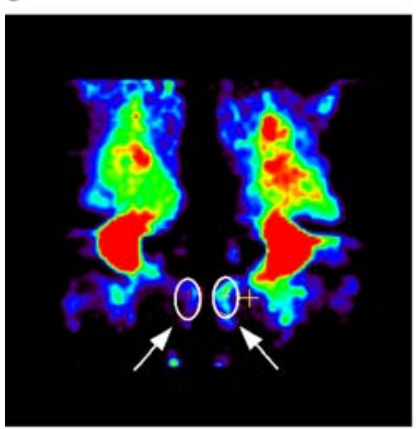

d

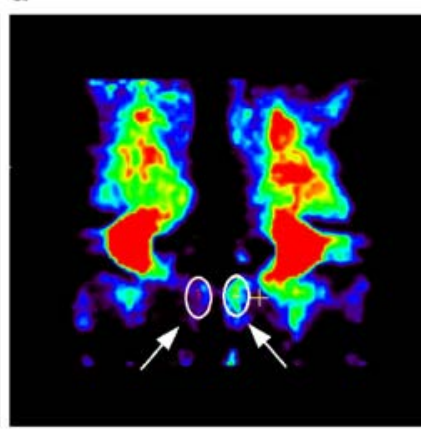

e

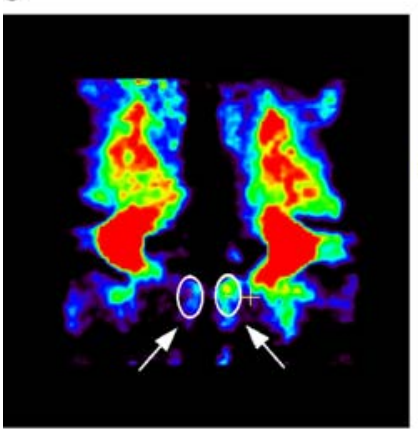

f

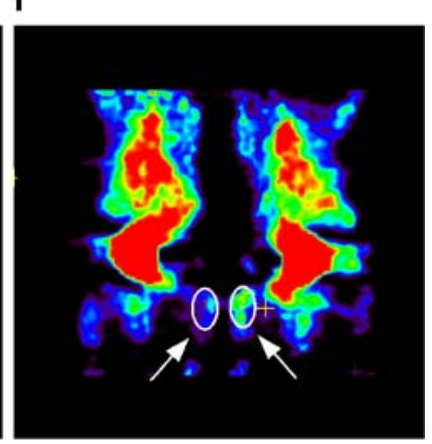

g



Fig. 3 Insulin-stimulated uptake of ${ }^{18} \mathrm{FDG}$ in wild-type and $\mathrm{Pten}^{+/-}$mice. Mice were fasted for $15 \mathrm{~h}$ prior to i.p. injection of $0.6 \mathrm{mU}$ insulin $/ \mathrm{g}$ body weight. Twenty minutes after insulin injection, mice were injected with ${ }^{18} \mathrm{FDG}$ via a tail vein, and whole-body distribution of ${ }^{18} \mathrm{FDG}$ was monitored by microPET for $60 \mathrm{~min}$. The experiment was repeated three times with similar results. Typical results are shown. a-f Imaging of ${ }^{18} \mathrm{FDG}$ distribution in coronal section; wildtype mouse is on the left and Pten $^{+/}$mouse is on the right (a $5 \mathrm{~min}$; b $15 \mathrm{~min}$; c $25 \mathrm{~min}$; d $35 \mathrm{~min}$; e $45 \mathrm{~min}$; f $55 \mathrm{~min}$ ). Hindlimb muscles were highlighted as regions of interest, and ${ }^{18} \mathrm{FDG}$ activity in each region of interest quantified across coronal planes at each time-point, as described in Materials and methods. g Graphical representation of relative ${ }^{18} \mathrm{FDG}$ activity. Data are shown as proportion of ${ }^{18} \mathrm{FDG}$ activity in hindlimbs relative to activity in whole body for wild-type mice (circles) and $\mathrm{Pten}^{+/-}$mice (triangles) (mean $\pm \mathrm{SD} ; n=3$ per point) 

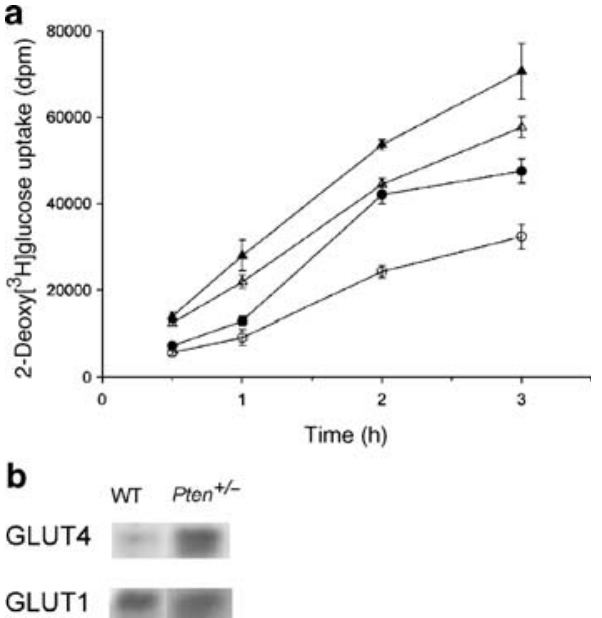

Fig. 4 a 2-Deoxy $\left[{ }^{3} \mathrm{H}\right]$ glucose uptake in wild-type and $\mathrm{Pten}^{+/-}$ myocytes. Myocytes were serum-starved for $12 \mathrm{~h}$ prior to incubation with $10 \mu \mathrm{mol} / 1$ 2-deoxy $\left[{ }^{3} \mathrm{H}\right]$ glucose $(0.037 \mathrm{MBq} / \mu \mathrm{mol} / \mathrm{l})$ for the indicated times with 0 or $1 \mu \mathrm{mol} / 1$ insulin. Following incubation cells were lysed and aliquots of lysates were taken for determination of radioactivity by scintillation counting. Means \pm SD for three separate determinations. White circles, wild-type cells $0 \mu \mathrm{mol} / 1$ insulin; black circles, wild-type cells $1 \mu \mathrm{mol} / 1$ insulin; white triangles, Pten ${ }^{+/-}$cells $0 \mu \mathrm{mol} / 1$ insulin; black triangles, Pten ${ }^{+/-}$cells $1 \mu \mathrm{mol} / 1$ insulin. b Cellsurface GLUT1 and GLUT4 levels. Levels of cell-surface GLUT1 and GLUT4 proteins in wild-type $(W T)$ and Pten $^{+/-}$cells were determined as described in Materials and methods

reduction of Pten on the regulation of insulin sensitivity in the context of the whole animal.

PTEN expression/activity is tightly regulated by a complex mechanism that is currently poorly understood. PTEN is transcriptionally regulated by transcription factors such as p53, Egr-1, NFKB and SMADs, while protein levels and activity are modulated by phosphorylation, oxidation, subcellular localisation, phospholipid binding and protein stability [29]. Previous studies showed that Pten haploinsufficiency results in only a $15-50 \%$ reduction in Pten protein, leaving a substantial amount of Pten protein remaining in the tissues examined [14, 22-24, 30]. In our hands, western blot analysis indicated similar decreases in tissue Pten levels (data not shown). The present study provides the first evidence that Pten haploinsufficiency leads to insulin hypersensitivity in vivo, suggesting that even small changes in Pten levels or activity can lead to dramatic effects on insulin responses. Thus partial systemic inhibition of PTEN activity may represent a novel strategy to ameliorate the pathology of type 2 diabetes.

The PI3K/PKB signalling axis is central to maintenance of normal glucose homeostasis [1]. Pten-deficient cells typically have elevated levels of intracellular $\mathrm{PIP}_{3}[31,32]$. The sustained phosphorylation of $\mathrm{PKB} / \mathrm{Akt}$ and a downstream effector, GSK $3 \beta$, observed in the current study is consistent with previous reports of elevated $\mathrm{PKB} / \mathrm{Akt}$ activation as a result of impaired desensitisation of PI3K- dependent signals under conditions of Pten inactivation or inhibition [9-11, 28]. A subtle reduction of Pten in the $\mathrm{Pten}^{+/-}$mice appears sufficient to achieve a prolonged and robust insulin signal. The roles of $\mathrm{PIP}_{3}$ and $\mathrm{PKB} / \mathrm{Akt}$ in insulin-mediated glucose uptake have been well-established; therefore, our data collectively suggest that sustained $\mathrm{PI} 3 \mathrm{~K} / \mathrm{PKB} / \mathrm{Akt} / \mathrm{GSK} 3$ signalling may, in part, contribute to insulin hypersensitivity in $\mathrm{Pten}^{+-}$mice. However, other PKB/Akt-independent signalling pathways, as well as additional signals delivered by the protein phosphatase and/or adaptor functions of Pten may also contribute to the insulin hypersensitivity phenotype manifested by Pten haploinsufficiency.

GLUT1 glucose transporters are constitutively present at the cell surface, while GLUT4 cycles between intracellular vesicles and the cell surface in a manner controlled by insulin-mediated signalling mechanisms [25]. In unstimulated fat and muscle cells, the majority of GLUT4 exists in intracellular compartments, while the insulin signal stimulates the exocytosis of GLUT4 to the cell surface. Studies involving $\mathrm{PKB} / \mathrm{Akt}$-null animals and silencing of $\mathrm{PKB} / \mathrm{Akt}$ by RNA interference have demonstrated that $\mathrm{PKB} / \mathrm{Akt}$ is of primary importance in GLUT4 translocation [33-36]. In the current study, we observed an enhancement of 2-deoxyglucose uptake in $\mathrm{Pten}^{+-}$cells even in the absence of insulin stimulation, which was consistent with our observation of increased biotinylation of GLUT4 at the cell surface, while GLUT1 levels were unaffected. However, we detected no increase in phosphorylation of PKB/Akt in the absence of insulin in $\mathrm{Pten}^{+/-}$cells. Consistent with these observations, a recent study in which Pten was specifically knocked down by RNA interference reported slight but significant enhancement of deoxyglucose uptake in adipocytes, but no apparent increase in phosphorylation of $\mathrm{PKB} /$ Akt [37]. These results could reflect a mechanism(s) affecting glucose transport involving Pten/PIP 3 but independent of $\mathrm{PKB} / \mathrm{Akt}$. Such a mechanism could involve the atypical protein kinases $\mathrm{C}-\lambda$ and $-\zeta$ (PKC- $\lambda$ and $\mathrm{PKC}-\zeta$ ),

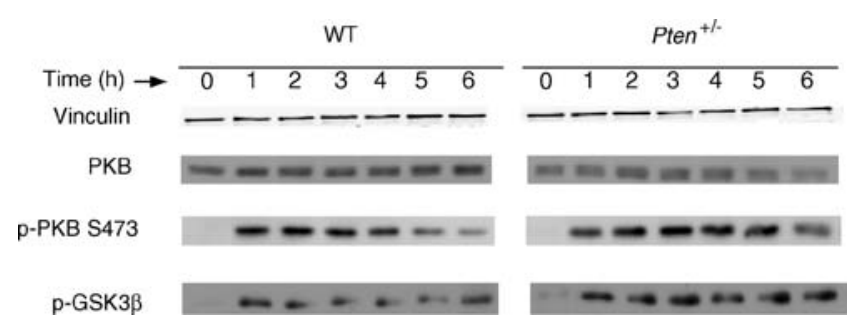

Fig. 5 Phosphorylation of PKB and GSK3 $\beta$. Myocytes were serumstarved for $12 \mathrm{~h}$ prior to incubation with $1 \mu \mathrm{mol} / 1$ insulin for the indicated times. Cell lysates were prepared, and proteins were separated by PAGE followed by western immunoblot analysis for vinculin, total PKB, phospho-PKB (p-PKB S473) and phosphoGSK3 $\beta$ (p-GSK3 $\beta$ ) as indicated. This experiment was repeated three times with typical results shown. WT, wild-type 
which, like $\mathrm{PKB} / \mathrm{Akt}$, are subject to control by $\mathrm{PI} 3 \mathrm{~K}$ via $\mathrm{PIP}_{3}$ and 3-phosphoinositide-dependent protein kinase-1 (PDK-1) [38-40]. A number of studies have implicated PKC $-\lambda / \zeta$ in insulin-stimulated glucose transport and GLUT4 translocation [38, 41-43]. These studies indicate a role for PKC- $\lambda / \zeta$ which appears to be complementary or parallel to that of $\mathrm{PKB} / \mathrm{Akt}$.

The importance of the PI3K pathway in insulin signalling has raised interest in developing pharmaceutical antagonists targeting $\mathrm{PIP}_{3}$ phosphatases such as PTEN or Sh2-containing inositol 5'-phosphatase 2 (SHIP2; also known as Inppl1) in an effort to enhance insulin responsiveness in type 2 diabetes [44]. While a study on Ship2null mice initially implicated Ship2 as a key regulator of glucose uptake [45], it was subsequently recognised that these mice also had deleted a neighbouring gene, Phox $2 a$, which may have contributed to the observed phenotype (corrigendum appears in Nature vol. 431, p. 878). A new gene-targeted mouse has since been generated in which only the gene encoding Ship2 is deleted [46]. Interestingly, this mouse does not exhibit insulin hypersensitivity but is protected against diet-induced obesity, [46, 47]. In the light of these new findings, our observations of dramatic enhancement of insulin sensitivity and glucose uptake resulting from Pten haploinsufficiency suggests that PTEN plays a role in the desensitisation of insulin signalling, and strengthens the hypothesis that PTEN is a key regulator of insulin-stimulated glucose uptake.

Type 2 diabetes is associated with insulin deficiency and resistance to insulin signalling [48, 49]. The current study provides further support for PTEN as a candidate for drug intervention in treating type 2 diabetes. However, enthusiasm for systemic PTEN inhibitors as a therapeutic approach for treating type 2 diabetes is tempered by the potential side-effects of such agents. Most notably, a modest reduction of Pten in $\mathrm{Pten}^{+/-}$mice promotes tumour formation in a wide variety of tissue, suggesting that long-term chronic administration of systemic PTEN inhibitors may lead to enhanced cancer development and progression. Furthermore, the PI3K pathway is an important regulator of numerous normal cellular processes and systemic PTEN inhibition may cause dysfunction of many cells and tissues, leading to alterations in liver, kidney, brain function, etc. For example, hepatocyte-specific Ptendeficient mice exhibit hepatomegaly and liver steatosis [9]. Systemic inhibition of PTEN may therefore be unacceptable clinically because of these inherent potential toxicities [44]. However, targeted delivery of PTEN antagonists to muscle cells or adipocytes may overcome these limitations and they hold promise as clinically viable agents in treatment of type 2 diabetes [44]. This study shows that partial inhibition of Pten is sufficient to enhance insulin sensitivity. This observation is important from a therapeutic standpoint, as most drugs are unlikely to completely inhibit enzyme activity in vivo, nor would complete inhibition be desirable given the potential for cancer development resulting from chronic or overactivation of the $\mathrm{PI} 3 \mathrm{~K} / \mathrm{PKB}$ pathway [12, 14, 23].

In conclusion, Pten haploinsufficiency results in insulin hypersensitivity, which underscores the importance of PTEN in attenuating insulin signals, and suggests that small-molecule drugs that antagonise PTEN activity may represent a novel class of insulin-sensitising agents and targeted delivery of these agents to muscle cells or adipocytes may have potential clinical utility in treating insulin resistance observed in type 2 diabetes.

Acknowledgements Funding was provided by a grant from Health Canada. J. T. Wong is a recipient of a fellowship from the Canadian Institutes of Health Research. We gratefully acknowledge the assistance of S. McCormick and D. Yapp with microPET, G. Smirnova with immunohistochemistry and Y. Chen for technical assistance. Polyclonal GLUT1 and GLUT4 antibodies were gifts of A. Klip.

Duality of interest The authors declare that no duality of interest exists relating to the subject matter of this manuscript.

\section{References}

1. Lizcano JM, Alessi DR (2002) The insulin signalling pathway. Curr Biol 12:R236-R238

2. Maehama T, Dixon JE (1998) The tumor suppressor, PTEN/ MMAC1, dephosphorylates the lipid second messenger, phosphatidylinositol 3,4,5-trisphosphate. J Biol Chem 273:13375-13378

3. Myers MP, Pass I, Batty IH et al (1998) The lipid phosphatase activity of PTEN is critical for its tumor suppressor function. Proc Natl Acad Sci USA 95:13513-13518

4. Li J, Yen C, Liaw D et al (1997) PTEN, a putative protein tyrosine phosphatase gene mutated in human brain, breast, and prostate cancer. Science 275:1943-1947

5. Steck PA, Pershouse MA, Jasser SA et al (1997) Identification of a candidate tumour suppressor gene, MMAC1, at chromosome $10 \mathrm{q} 23.3$ that is mutated in multiple advanced cancers. Nat Genet $15: 356-362$

6. Di Cristofano A, Pesce B, Cordon-Cardo C, Pandolfi PP (1998) Pten is essential for embryonic development and tumour suppression. Nat Genet 19:348-355

7. Guldberg P, thor Straten P, Birck A, Ahrenkiel V, Kirkin AF, Zeuthen J (1997) Disruption of the MMAC1/PTEN gene by deletion or mutation is a frequent event in malignant melanoma. Cancer Res 57:3660-3663

8. Risinger JI, Hayes AK, Berchuck A, Barrett JC (1997) PTEN/ MMAC1 mutations in endometrial cancers. Cancer Res 57:47364738

9. Stiles B, Wang Y, Stahl A et al (2004) Liver-specific deletion of negative regulator Pten results in fatty liver and insulin hypersensitivity. Proc Natl Acad Sci USA 101:2082-2087

10. Wijesekara N, Konrad D, Eweida M et al (2005) Muscle-specific Pten deletion protects against insulin resistance and diabetes. Mol Cell Biol 25:1135-1145

11. Kurlawalla-Martinez C, Stiles B, Wang Y, Devaskar SU, Kahn $\mathrm{BB}, \mathrm{Wu} \mathrm{H}$ (2005) Insulin hypersensitivity and resistance to streptozotocin-induced diabetes in mice lacking PTEN in adipose tissue. Mol Cell Biol 25:2498-2510 
12. Podsypanina K, Ellenson LH, Nemes A et al (1999) Mutation of Pten/Mmac1 in mice causes neoplasia in multiple organ systems. Proc Natl Acad Sci USA 96:1563-1568

13. Di Cristofano A, Kotsi P, Peng YF, Cordon-Cardo C, Elkon KB, Pandolfi PP (1999) Impaired Fas response and autoimmunity in Pten+/- mice. Science 285:2122-2125

14. Kwabi-Addo B, Giri D, Schmidt K et al (2001) Haploinsufficiency of the Pten tumor suppressor gene promotes prostate cancer progression. Proc Natl Acad Sci USA 98:11563-11568

15. Verchere CB, D'Alessio DA, Prigeon RL, Hull RL, Kahn SE (2000) The constitutive secretory pathway is a major route for islet amyloid polypeptide secretion in neonatal but not adult rat islet cells. Diabetes 49:1477-1484

16. Verchere CB, Kowalyk SD, Koerker J, Baskin DG, Taborsky GJJ (1996) Evidence that galanin is a parasympathetic, rather than sympathetic, neurotransmitter in the baboon pancreas. Regul Pept 67:93-101

17. Springer ML, Rando T, Blau HM (1997) Gene delivery to muscle. In: Boyle AL (ed) Current protocols in human genetics, vol. 13.4. Wiley, New York, NY, pp 1-19

18. Rosenblatt JD, Parry DJ, Partridge TA (1996) Phenotype of adult mouse muscle myoblasts reflects their fiber type of origin. Differentiation 60:39-45

19. Taverna RD, Langdon RG (1973) Reversible association of cytochalasin B with the human erythrocyte membrane. Inhibition of glucose transport and the stoichiometry of cytochalasin binding. Biochim Biophys Acta 323:207-219

20. Vaag A, Henriksen JE, Beck-Nielsen H (1992) Decreased insulin activation of glycogen synthase in skeletal muscles in young nonobese Caucasian first-degree relatives of patients with non-insulin-dependent diabetes mellitus. J Clin Invest 89: 782-788

21. Pauwels EKJ, Sturm EJC, Bombardieri E, Cleton FJ, Stokkel MPM (2000) Positron-emission tomography with $\left[{ }^{18} \mathrm{~F}\right]$ fluorodeoxyglucose. Part I. Biochemical uptake mechanism and its implication for clinical studies. J Cancer Res Clin Oncol 126: $549-559$

22. Wang H, Douglas W, Lia M et al (2002) DNA mismatch repair deficiency accelerates endometrial tumorigenesis in Pten heterozygous mice. Am J Pathol 160:1481-1486

23. Kim MJ, Cardiff RD, Desai N et al (2002) Cooperativity of Nkx3.1 and Pten loss of function in a mouse model of prostate carcinogenesis. Proc Natl Acad Sci USA 99:2884-2889

24. Podsypanina K, Lee RT, Politis C et al (2001) An inhibitor of mTOR reduces neoplasia and normalizes p70yS6 kinase activity in Pten+/- mice. Proc Natl Acad Sci USA 98:10320-10325

25. Thong FSL, Dugani CB, Klip A (2005) Turning signals on and off: GLUT4 traffic in the insulin-signaling highway. Physiology 20:271-284

26. Alessi DR, Andjelkovic M, Caudwell B et al (1996) Mechanism of activation of protein kinase B by insulin and IGF-1. EMBO J 15:6541-6551

27. Scheid MP, Woodgett JR (2003) Unravelling the activation mechanisms of protein kinase B/Akt. FEBS Lett 546:108-112

28. Butler M, McKay RA, Popoff IJ et al (2002) Specific inhibition of PTEN expression reverses hyperglycemia in diabetic mice. Diabetes 51:1028-1034

29. Leslie NR, Downes CP (2004) PTEN function: how normal cells control it and tumour cells lose it. Biochem J 382:1-11

30. Trotman LC, Niki M, Dotan ZA et al (2003) Pten dose dictates cancer progression in the prostate. PLoS Biol 1:385-396

31. Stambolic V, Suzuki A, de la Pompa JL et al (1998) Negative regulation of $\mathrm{PKB} / \mathrm{Akt}$-dependent cell survival by the tumor suppressor PTEN. Cell 95:29-39
32. Sun H, Lesche R, Li DM et al (1999) PTEN modulates cell cycle progression and cell survival by regulating phosphatidylinositol 3,4,5,-trisphosphate and Akt/protein kinase B signaling pathway. Proc Natl Acad Sci USA 96:6199-6204

33. Cho H, Mu J, Kim JK et al (2001) Insulin resistance and a diabetes mellitus-like syndrome in mice lacking the protein kinase Akt2 (PKB beta). Science 292:1728-1731

34. Katome T, Obata T, Matsushima R et al (2003) Use of RNA interference-mediated gene silencing and adenoviral overexpression to elucidate the roles of AKT/protein kinase B isoforms in insulin actions. J Biol Chem 278:28312-28323

35. Jiang ZY, Zhou QL, Coleman KA, Chouinard M, Boese Q, Czech MP (2003) Insulin signaling through Akt/protein kinase B analyzed by small interfering RNA-mediated gene silencing. Proc Natl Acad Sci USA 100:7569-7574

36. Bae SS, Cho H, Mu J, Birnbaum MJ (2003) Isoform-specific regulation of insulin-dependent glucose uptake by Akt/protein kinase B. J Biol Chem 278:49530-49536

37. Tang X, Powelka AM, Soriano NA, Czech MP, Guilherme A (2005) PTEN, but not SHIP2, suppresses insulin signaling through the phosphatidylinositol 3-kinase/Akt Pathway in 3T3L1 adipocytes. J Biol Chem 280:22523-22529

38. Farese RV (2002) Function and dysfunction of aPKC isoforms for glucose transport in insulin-sensitive and insulin-resistant states. Am J Physiol Endocrinol Metab 283:E1-E11

39. Bandyopadhyay G, Standaert ML, Sajan MP et al (1999) Dependence of insulin-stimulated glucose transporter 4 translocation on 3-phosphoinositide-dependent protein kinase-1 and its target threonine-410 in the activation loop of protein kinase Czeta. Mol Endocrinol 13:1766-1772

40. Standaert ML, Bandyopadhyay G, Perez L et al (1999) Insulin activates protein kinases C-zeta and C-lambda by an autophosphorylation-dependent mechanism and stimulates their translocation to GLUT4 vesicles and other membrane fractions in rat adipocytes. J Biol Chem 274:25308-25316

41. Bandyopadhyay G, Standaert ML, Sajan MP et al (2004) Protein kinase C-lambda knockout in embryonic stem cells and adipocytes impairs insulin-stimulated glucose transport. Mol Endocrinol 18:373-383

42. Bandyopadhyay G, Standaert ML, Kikkawa U, Ono Y, Moscat J, Farese RV (1999) Effects of transiently expressed atypical (zeta, lambda), conventional (alpha, beta) and novel (delta, epsilon) protein kinase $\mathrm{C}$ isoforms on insulin-stimulated translocation of epitope-tagged GLUT4 glucose transporters in rat adipocytes: specific interchangeable effects of protein kinases C-zeta and Clambda. Biochem J 337:461-470

43. Kotani K, Ogawa W, Matsumoto M et al (1998) Requirement of atypical protein kinase $\mathrm{C}$-lamda for insulin stimulation of glucose uptake but not for Akt activation in 3T3-11 adipocytes. Mol Cell Biol 18:6971-6982

44. Lazar DF, Saltiel AR (2006) Lipid phosphatases as drug discovery targets for type 2 diabetes. Nat Rev Drug Discov 5:333-342

45. Clement S, Krause U, Desmedt F et al (2001) The lipid phosphatase SHIP2 controls insulin sensitivity. Nature 409:9297

46. Sleeman MW, Wortley KE, Lai K-MV et al (2005) Absence of the lipid phosphatase SHIP2 confers resistance to dietary obesity. Nat Med 11:199-205

47. Decker SJ, Saltiel AR (2005) Staying in SHIP shape. Nat Med $11: 123-124$

48. Lebovitz HE (1999) Type 2 diabetes: an overview. Clin Chem 45:1339-1345

49. Bloomgarden ZT (1998) Insulin resistance: current concepts. Clin Ther 20:216-231 